\title{
sciendo EXPERIMENTAL RESEARCH OF SELF-IGNITION ENGINE FUELED BY MIXTURE OF DIESEL AND SYNTHETIC FUEL
}

DOI 10.2478/ntpe-2018-0068

\author{
Prof. Dr. Eng. Oleh Klyus \\ Maritime University of Szczecin, Poland \\ MSc. Eng. Anna Skarbek-Żabkin \\ Motor Transport Institute, Poland \\ Nadezhda Zamiatina, PhD student \\ Klaipeda University, Lithuania
}

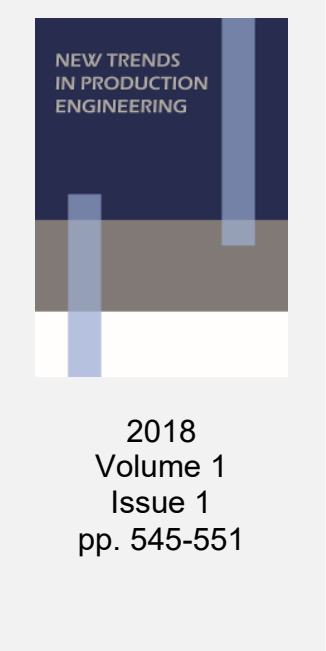

\begin{abstract}
The paper presents the bench tests' results of a swirl chamber engine fed with a mixture of petroleum and synthetic fuels. Synthetic fuel comes from the processing of polymeric waste and its content in the mixture equaled to $7 \%$. According to the results, the basic operational parameters of the engine did not change significantly. A minor increase in $\mathrm{NO}_{2}$ emissions was observed, which may be explained by the increased combustion temperature. Simultaneously, the reduction of the smoke was obtained.
\end{abstract}

Keywords: internal combustion engine, synthetic fuel, petroleum and synthetic fuels

\section{INTRODUCTION}

The development of piston engines is mainly directed to reduce the toxic compounds emission in the exhaust gas and to improve their efficiency and performance. For this purpose, electronic control of the fuel injection process (Ashgriz, 2001; Klyus and Klyus, 2011) and modern design of combustion chambers were used as well as various reducing and oxidizing devices in the exhaust system (Merkisz et al., 2016; Fajnlejb B., 1989). All this may be specified as combustion process optimization and the reduction process of the toxicity of exhaust gases (Ambrozik, 2003). However, it should be noted that this approach fails to take into consideration one more factor namely what a combustion chamber is fed with (Hejwood, 1988). Liquid fuel in the form of diesel fuel or its mixture with biocomponents (Demirbas, 2008; Deshmukh et al., 2012) is commonly used in automotive transport. However, emerging products in the form of synthetic fuels produced from polymeric materials may be an alternative to currently used fuels. The Maritime University of Szczecin and the Motor Transport Institute of Warsaw cooperate in terms of research on using the petroleum and synthetic fuels' mixture being a recycle product of polymeric waste in internal combustion engines.

\section{LABORATORY TESTS}

As it is commonly known (Włosiński, 2016), polymeric materials may be recycled in the raw materials, chemical, and energy recycling process. Joined chemical and energy recycling enables the production of liquid fuels that may be used in piston engines. The waste treatment process occurs through a catalytic transformation of the batch. The transformation takes place inside the system and results in depolymerization which means that polymer materials, temperature triggered, without air and combustion process in the atmospheric pressure environment, are decomposed. The raw materials for this process are mainly polyolefins polyethylene and polypropylene (Klyus, O., Skarbek-Żabkin, A., 2015). Chemically, they are polyolefine waste. For the purpose of the laboratory tests and bench testing, synthetic fuel, being a product of polymeric waste recycle process of T-Technology, was selected. 
The laboratory tests of petroleum fuel and its mixture with synthetic fuel were conducted at the Fuel Research, Hydraulic Fluids and Environmental Protection Centre of the Maritime University of Szczecin. The content of the synthetic fuel in the mixture was $7 \%$ due to the minimum ignition temperature (550C) under PN-EN590:2013. If the content of the synthetic fuel in the mixture is higher, the ignition temperature decreases and exceeds the acceptable limit. The test results are presented in Table 1.

Table 1.

Fuel physical parameters.

\begin{tabular}{|l|c|c|c|}
\hline \multicolumn{1}{|c|}{ Parameter } & Unit & $\mathbf{1 0 0 \%}$ ON & $\mathbf{7 \%}$ FR+ON \\
\hline Density at $15^{\circ} \mathrm{C}$ & $\mathrm{kg} / \mathrm{m}^{3}$ & 834 & 833 \\
\hline Viscosity at $40^{\circ} \mathrm{C}$ & $\mathrm{mm}^{2} / \mathrm{s}$ & 2.768 & 2.672 \\
\hline Cetane number & & 55.8 & 56.9 \\
\hline Flash point & ${ }^{\circ} \mathrm{C}$ & 65.0 & 55.0 \\
\hline Cold filter plugging point (CFPP) & ${ }^{\circ} \mathrm{C}$ & -4.0 & \\
\hline Cloud point & ${ }^{\circ} \mathrm{C}$ & -3.0 & \\
\hline Pour point & ${ }^{\circ} \mathrm{C}$ & -13.0 & \\
\hline Water content & $\mathrm{mg} / \mathrm{kg}$ & 49.9 & \\
\hline Carbon residue & $\%$ & 0.09 & 0.30 \\
\hline Total contamination & $\mathrm{mg} / \mathrm{kg}$ & 0.03 & 0.02 \\
\hline Lubricity & $\%$ & 347 & 460 \\
\hline Distillation recovered at $250^{\circ} \mathrm{C}$ & $\%$ & 35 & \\
\hline Distillation recovered at $350^{\circ} \mathrm{C}$ & $\%$ & 92 & \\
\hline 95\% (V/V) recovered at & ${ }^{\circ} \mathrm{C}$ & 363.9 & 318.0 \\
\hline
\end{tabular}

Source: (Own research, 2017).

It should be underlined that the basic physical parameters of diesel fuel and synthetic fuel such as cetane number, viscosity and density are practically identical.

\section{BENCH TESTING}

Experimental research was conducted at the brake test bench (Fig. 1.), equipped with a diesel engine - 4CTi90-1BE6. The selection of that engine was not random since it has been commonly used in commercial vehicles in which the use of fuels in the form of diesel fuel mixture with recycled fuel may be an alternative to fuels of vegetable origin without special changes in the design of both combustion chamber and injection systems.

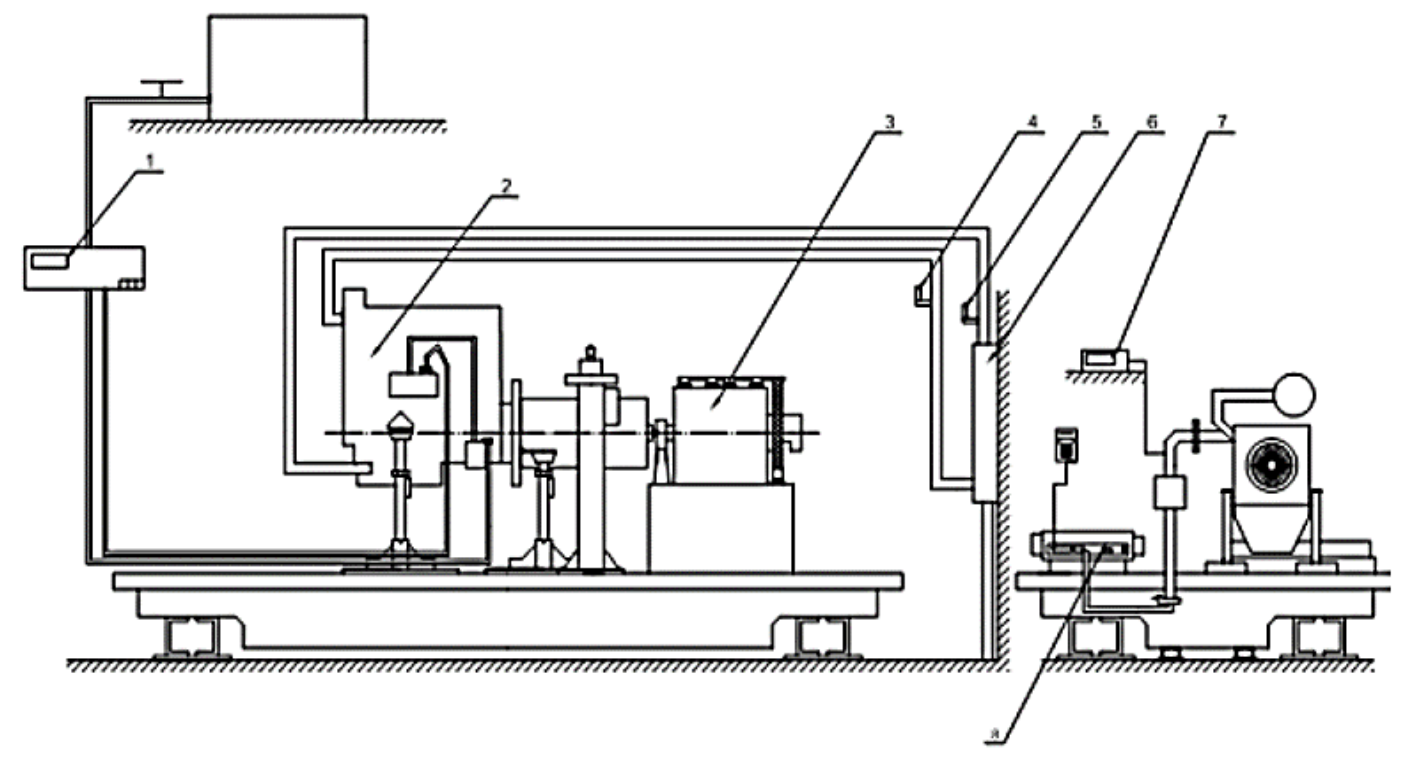

Fig. 1. Scheme of the test stand

1 - measuring instrument AMX212F, 2 - engine 4CTi90, 3 - Dynoperform 160 brake, 4 - coolant thermometer, 5 - coolant thermometer, 6 - coolant tank,

7 - exhaust gas temperature measuring instrument, 8 -MDO 2 opacimeter with control panel. 
Engine ANDORIA 4CTi90-1BE6 is equipped with a combustion chamber Ricardo Comet Mark $V$ (Fig. 2) loaded by an eddy current brake with variable load values given - AVL Dynoperform 160 (Fig. 3). The fuel consumption was measured by a measuring instrument (AUTOMEX AMX 212F), exhaust gas analyzer (Testo 350 MARITIME V2) and opacimeter (MDO-2).

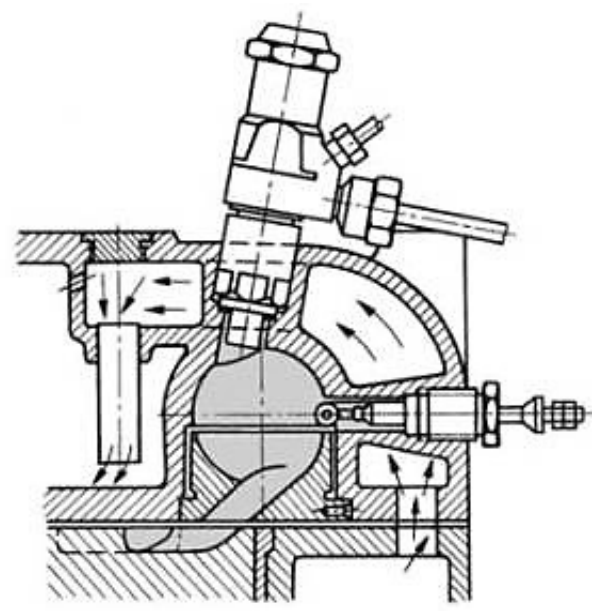

Fig. 2. Cross section of the combustion chamber Ricardo Comet Mark V of the 4CTi90-1BE6 engine.

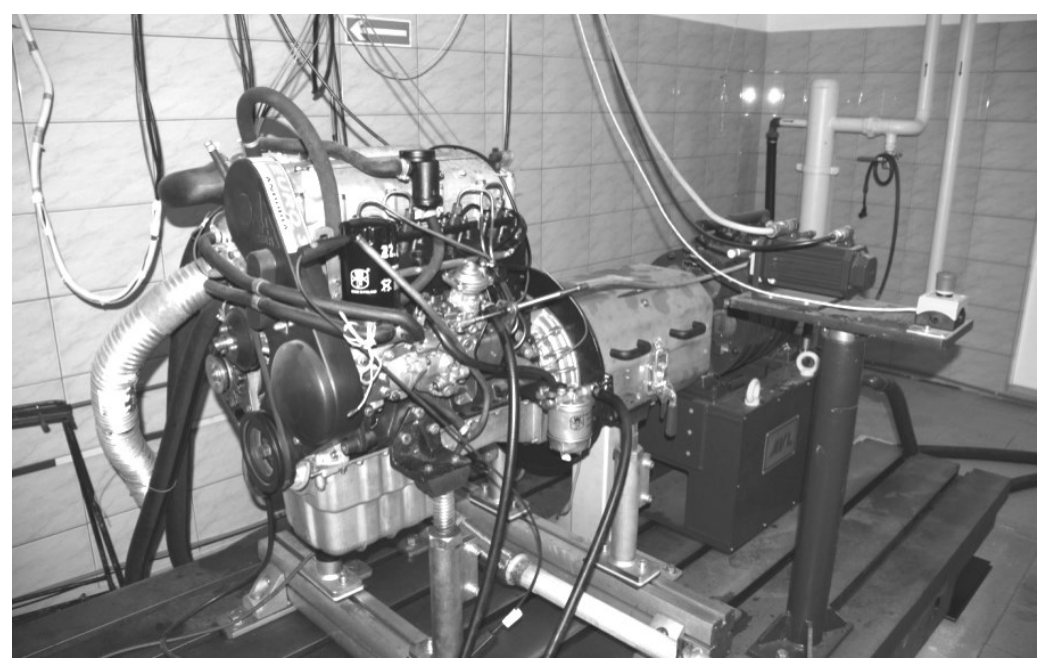

Fig. 3. Test stand view.

The diesel engine technical parameters, measurement ranges applied to the exhaust gas analyzer, the fuel consumption meter and the opacimeter are as follows:

\section{Engine ANDORIA 4CTI90-1BE6}

\section{Type}

Piston stroke/cylinder diameter

Compression ratio

Rated power

Maximum torque four-stroke, four-cylinder diesel engine,

95/90 mm

21.1

$66 \mathrm{~kW}$

$205 \mathrm{Nm}(2500$ 1/min $)$

\section{Exhaust gas analyzer Testo $\mathbf{3 5 0}$ MARITIME V2}

Measurement parameter

Exhaust gas temperature

$\mathrm{O}_{2}$

$\mathrm{CO}$

$\mathrm{NO}_{2}$

$\mathrm{CO}_{2}$
Measurement range

$0 \mathrm{C}-40 \div 1000$

$0 \div 25 \%$

$0 \div 3000 \mathrm{ppm}$

$0 \div 3000 \mathrm{ppm}$

$0 \div 40 \%$ 
Fuel consumption meter AUTOMEX AMX 212F

Minimum flow rate

$0.2 \mathrm{~g} / \mathrm{s}$

Minimum measurement accuracy

$0.2 \%$

Sampling frequency

$19.2 \mathrm{~Hz}$

Fuel volume in meter

$900 \mathrm{~g}$

Opacimeter MDO-2

Measurement method

Processor

Smoke measurement range

Absorption coefficient

absorption photometry

Hitachi $\mathrm{H} 8 / 532$, flash E-prom

$0 \div 100 \%$

$0 \mathrm{~m}$

Figures 4-11 present the bench tests results of the 4CTi90-1BE6 engine fed with diesel fuel $(\mathrm{ON})$ and a mixture of diesel oil with $7 \%$ synthetic oil $(\mathrm{ON}+7 \% \mathrm{FR})$ in the form of speed characteristics.

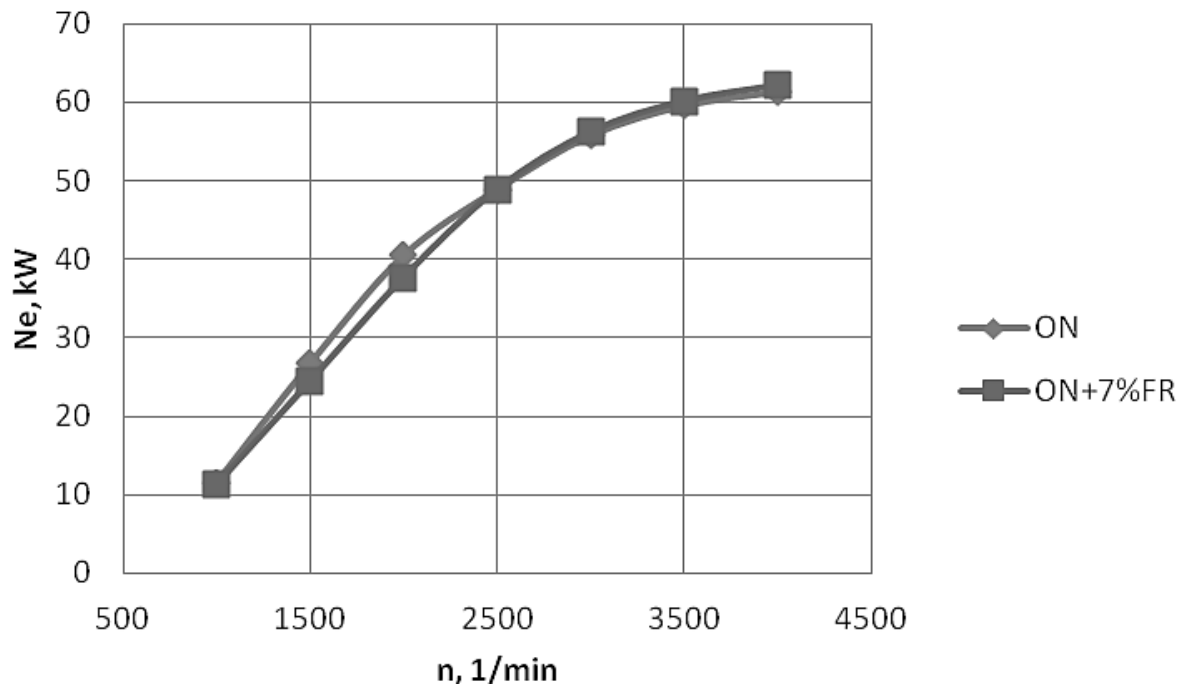

Fig. 4. External characteristic of the 4CTi90-1BE6 engine power.

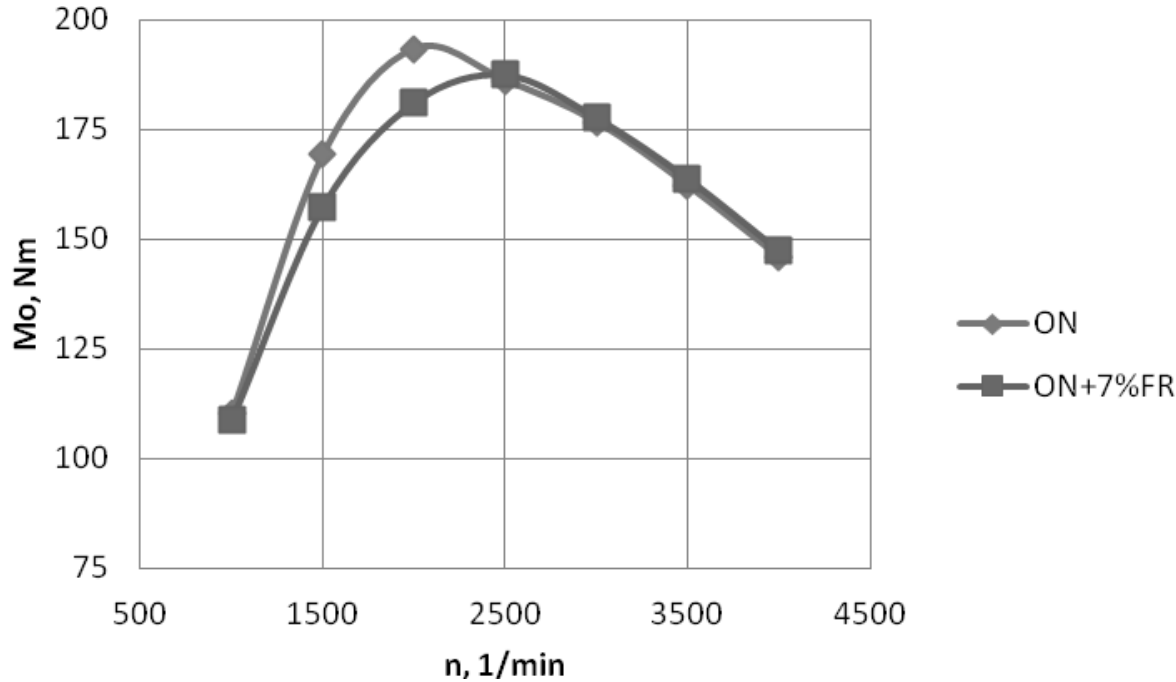

Fig. 5. External characteristic of the 4CTi90-1BE6 engine torque. 


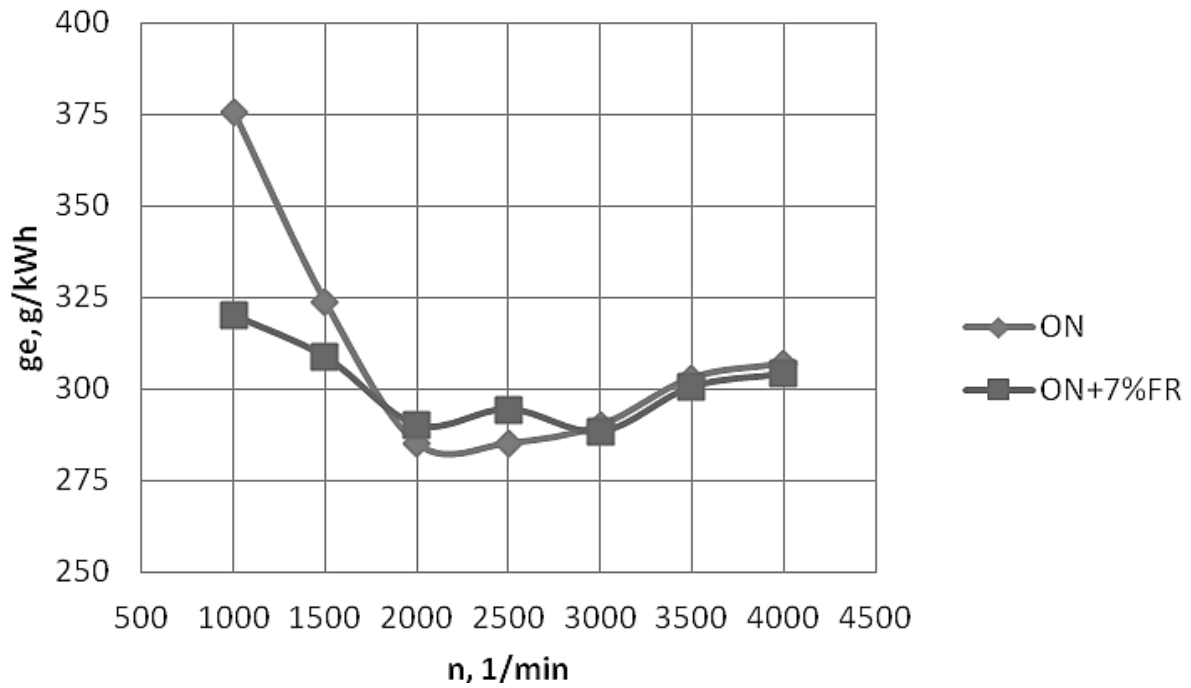

Fig. 6. Unit fuel consumption of the 4CTi90-1BE6 engine.

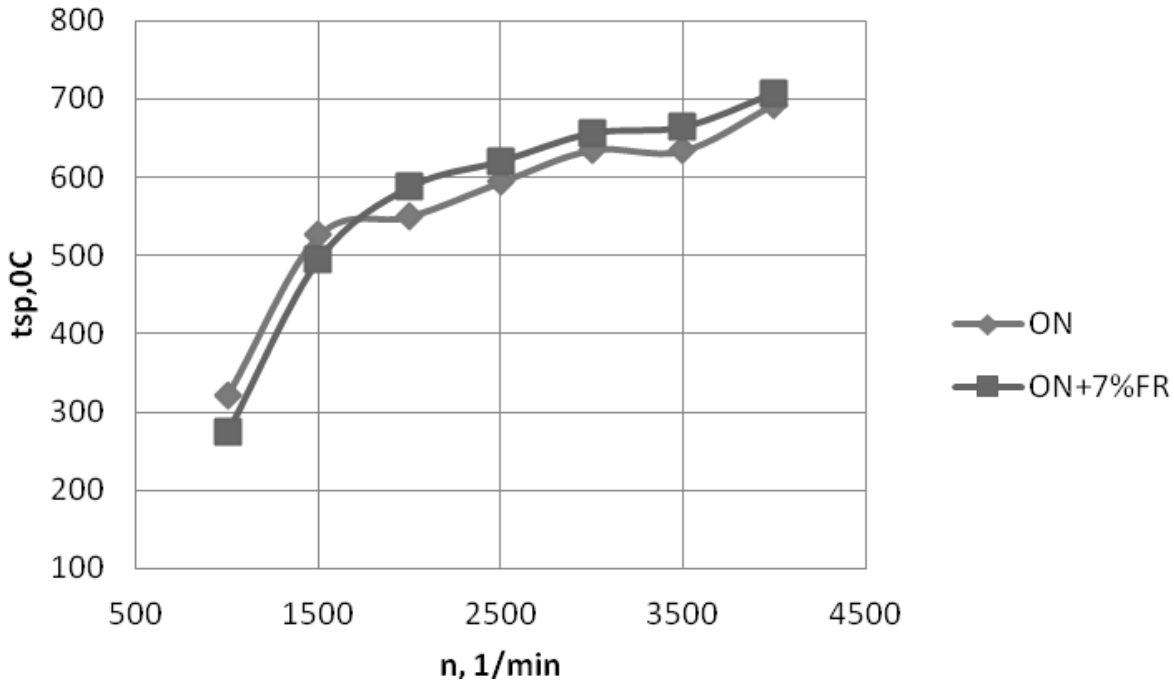

Fig. 7. Exhaust gas temperature for the 4CTI90-1BE6 engine.

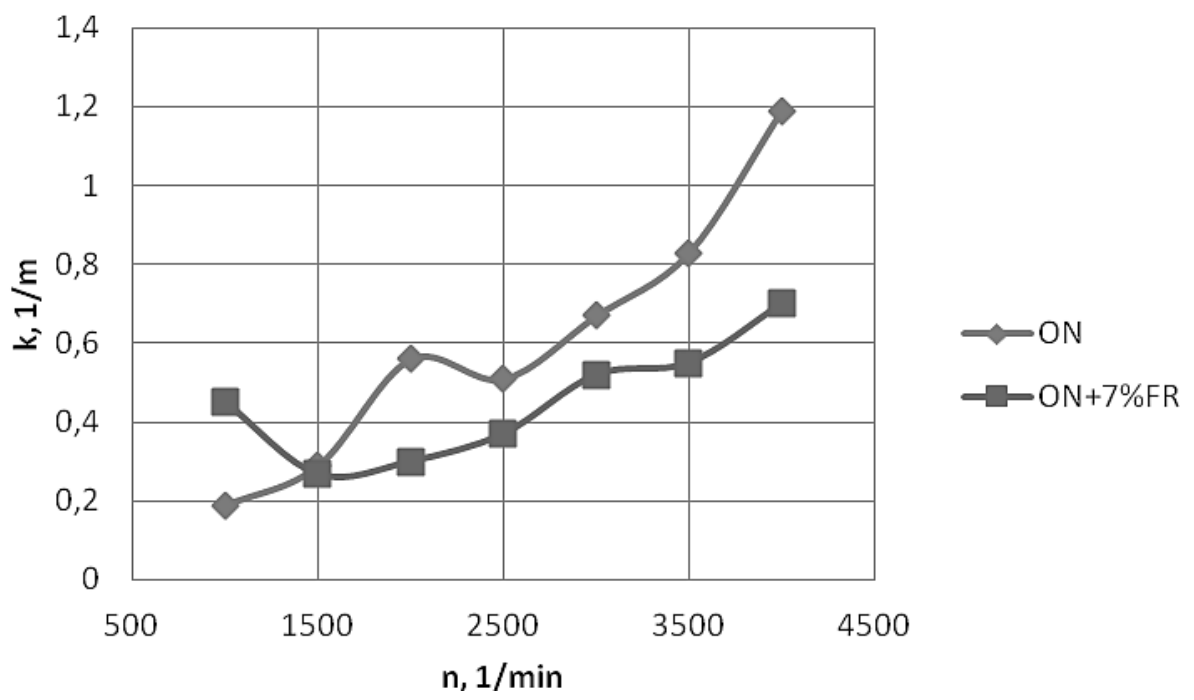

Fig. 8. Smoke level for the 4CTI90-1BE6 engine. 


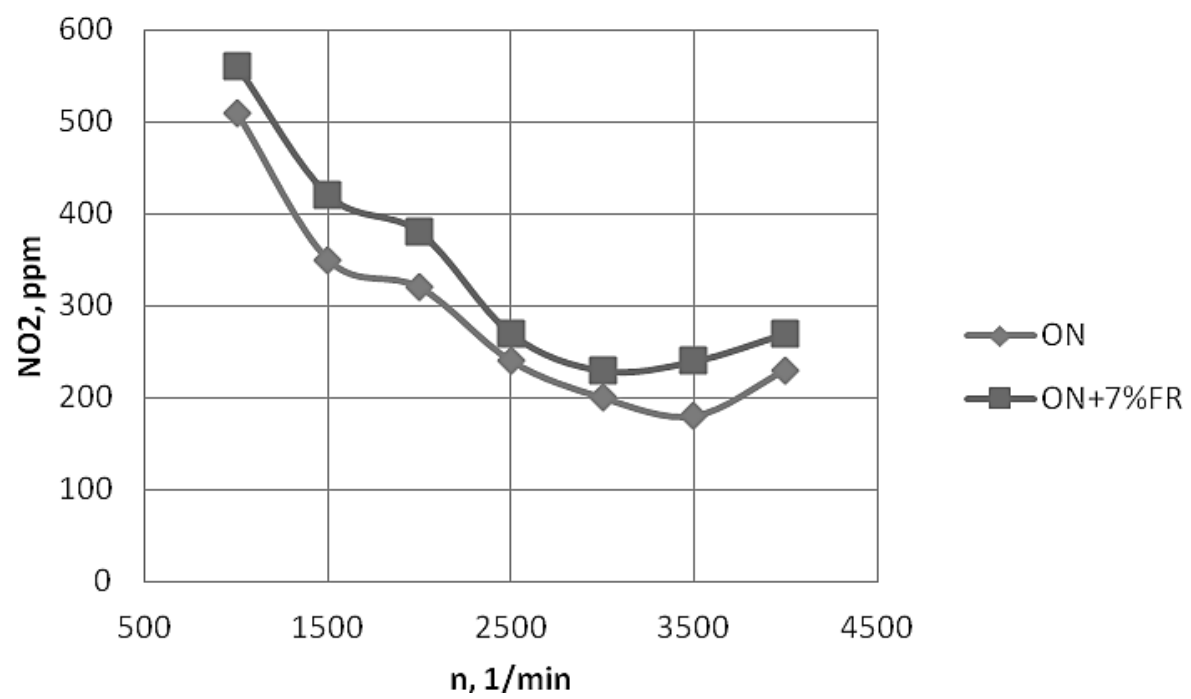

Fig. 9. Nitrogen dioxide emissions for the 4CTI90-1BE6 engine.

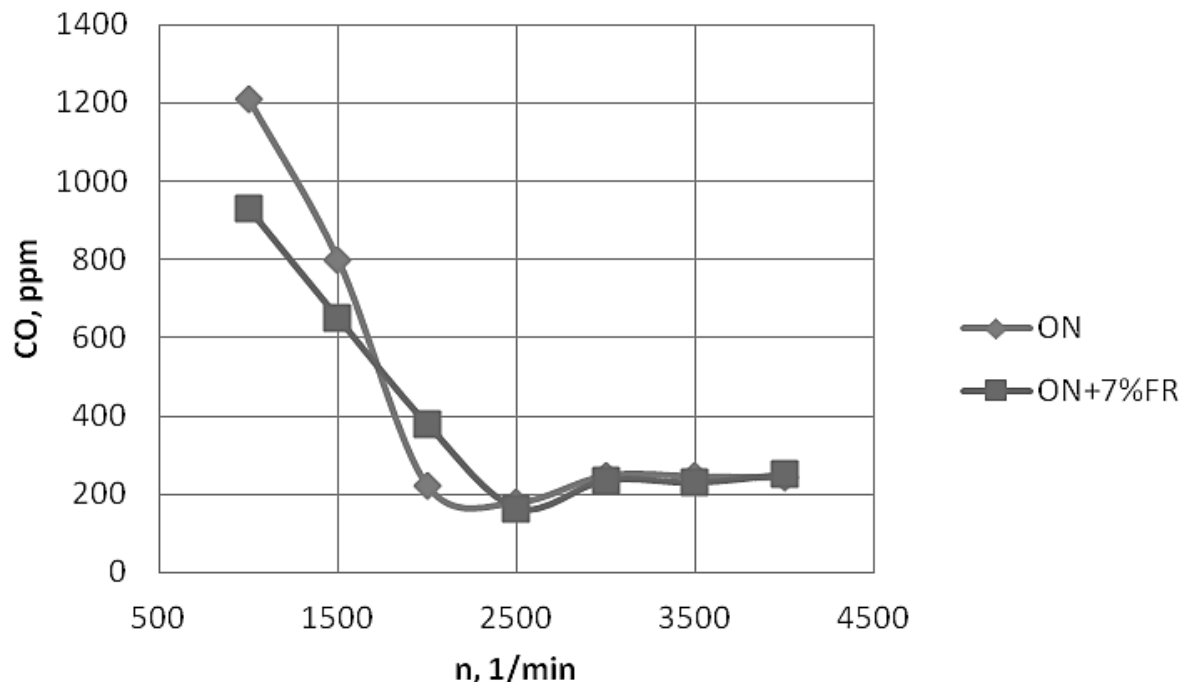

Fig. 10. Emission of carbon monoxide for the 4CTI90-1BE6 engine.

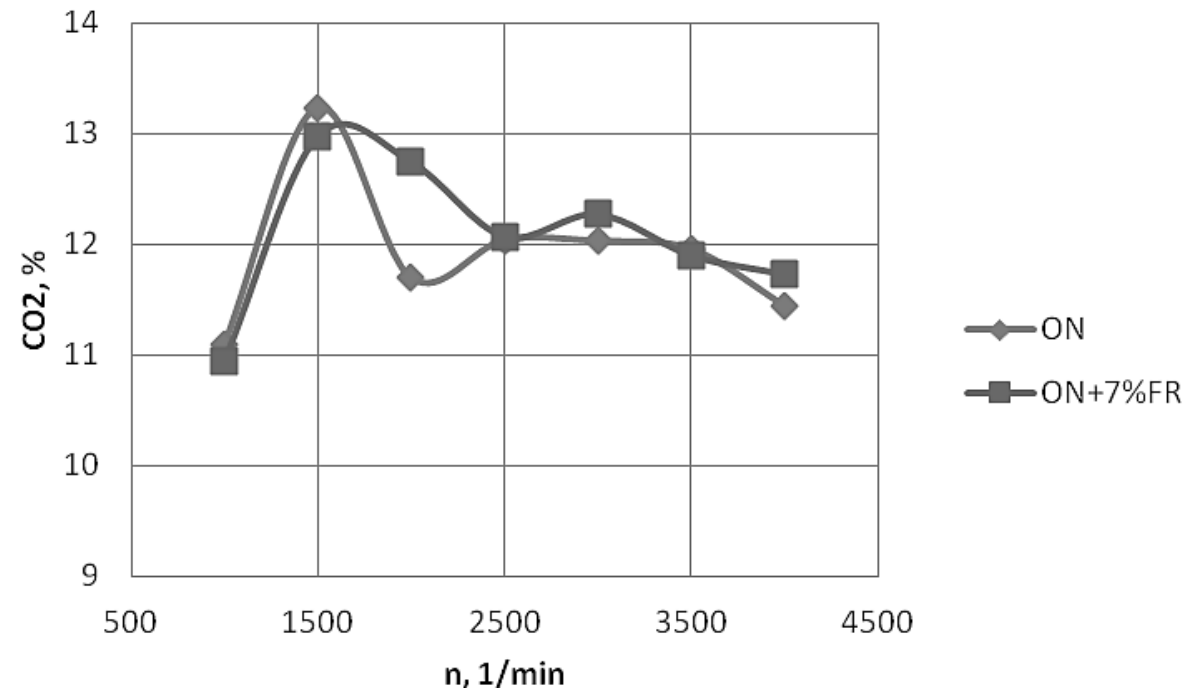

Fig. 11. Emission of carbon dioxide for the 4CTI90-1BE6 engine.

As the bench tests' results show, the basic operational parameters for the said engine fueled with diesel fuel and a mixture of diesel oil with $7 \%$ synthetic oil are practically identical in terms 
of power, torque and unit fuel consumption for the rotational frequency above $25001 / \mathrm{min}$. Increased emission of nitrogen dioxide may be a consequence of the increased temperature of the operating process. It may be proved by the temperature measurement of the exhaust gas and by lowered smoke level. However, decreased operational parameters of the engine in the crankshaft rotational frequency below $25001 /$ min may be associated with lower distillation temperature of the mixture. As a result, a fuel and air mixture may be poorer in the physical part of the self-ignition delay period (Fajnlejb B. 1989). This is proved by the measurement of carbon monoxide emission for the exhaust gas.

\section{CONCLUSIONS}

Using synthetic fuels, mixed with diesel fuel, enables obtaining effects in the form of municipal waste recycling and the production of liquid fuels for the automotive industry. The results of the laboratory tests and the bench tests, carried out at the Maritime University of Szczecin, present the option of direct use in diesel engines mixtures of petroleum diesel oil with $7 \%$ synthetic fuel from the recycled waste polymeric materials. It should be underlined that the applied value of $7 \%$ of additives, due to the limited minimum temperature of fuel self-ignition, is compliant with PN-EN590:2009 on the physical properties that all automotive diesel fuel must meet if it is to be sold and that may include up to $7 \%$ of V/V biocomponents. Further research and development work should be directed to a thorough analysis of the engine's operating process, taking into account the changes in its control parameters.

\section{ACKNOWLEDGEMENTS}

This research outcome has been achieved under the research project No 1/S/IESO/2014 financed from a subsidy of the Ministry of Science and Higher Education for statutory activities

\section{REFERENCES}

Ambrozik, A. (2003). Wybrane zagadnienia procesów cieplnych w tłokowych silnikach spalinowych. Kielce: Wydawnictwo Politechniki Świętokrzyskiej.

Ashgriz, N. (2001). Handbook of Atomization and Sprays, Theory and Applications. Springer Science+Business Media.

Demirbas A. (2008). Biodiesel - A Realistic Fuel Alternative for Diesel Engines, Springer.

Deshmukh, D., Madan Mohan, A., Anand, T. and Ravikrishna R. (2012). Spray characterization of straight vegetable oils at high injection pressures, Fuel 97, pp. 879883 ,

Hejwood, J. (1988). Internal combustion engines fundamentals. McCraw - Hill Book Co.

Klyus, O., and Klyus, I. (2011). The theory of the turbulization process in the fuel spray injector of compression ignition engines. Scientific Journals Maritime University of Szczecin, 27(99), pp.46-54.

Skarbek-Żabkin, A. (2015). Metodika opriedielijenia kacziestwa rspyłiwania topliwa połucziennowo pri recyklingie awtomobililjej. Wara: Izdatielstwo PW, pp. 34-40.

Włosiński J. (2016). Recykling. Warszawa: WGW.

Merkisz, J., Pielecha, I., Radzimski S. (2016). New trends in emission control in the European Union. Springer.

Fajnlejb B. (1989) Topliwnaja apparatura awtotraktornych dizliejej. Maszinostrojenie.

Date of submission of the article to the Editor: 07/2018

Date of acceptance of the article by the Editor: 09/2018 